\title{
Othonella araguaiana (Bivalvia, Megadesmidae) from the Corumbataí Formation (Midlle Permian), Eastern Margin of the Paraná Basin: Systematic, Evolutionary and Biostratigraphic Significances
}

\author{
Othonella araguaiana Mendes (Bivalvia, Megadesmidae), Formação Corumbataí \\ (Permiano Superior) da Margem Leste da Bacia do Paraná: \\ Significado Sistemático, Evolutivo e Bioestratigráfico
}

\author{
Marcello Guimarães Simões' (błsimoes@ibb.unesp.br), Luiz Eduardo Anelli² (anelli@usp.br), \\ Juliana Machado David ${ }^{3}$ (juliana_mdavid@yahoo.com.br) \\ 'Instituto de Biociências - UNESP \\ Distrito de Rubião Júnior s/n, CEP 181610-000, Botucatu, SP, BR \\ ${ }^{2}$ Departamento de Geologia Sedimentar e Ambiental - Instituto de Geociências - USP, São Paulo, SP, BR \\ ${ }^{3}$ Instituto de Geociências e Ciências Exatas - UNESP, Rio Claro, SP, BR
}

Received 24 August 2009; accepted 16 March 2010

\begin{abstract}
In this study, the occurrence of Othonella araguaiana Mendes, a rare bivalve species is reported for the first time in the Pinzonella illusa biozone, Middle Permian Corumbataí Formation, in the State of São Paulo. This species was originally described in coeval rocks of the Estrada Nova Formation (= Corumbataí) from the Alto Araguaia and Alto Garças regions, State of Mato Grosso. The specimens of $O$. araguaiana were found in the base of a bioclastic sandstone bed, a proximal tempestite, in the middle of the Corumbataí Formation, in the city of Rio Claro, São Paulo State. The silicified shells and internal molds are well preserved, showing impressions of muscle scars and other internal anatomic characters (e.g., hinge), never illustrated by previous authors. In his original description, Mendes (1963) called attention to the similarity between $O$. araguaiana and Terraia aequilateralis, a common veneroid of the Corumbataí Formation. Conversely, Runnegar and Newell (1971) suggested that $O$. araguaiana belongs to Megadesmidae, being a junior synonym of Plesiocyprinella carinata (the commonest megadesmid of the Passa Dois Group). Our study indicates that $O$. araguaiana is indeed a megadesmid, but is distinct from the $P$. carinata. The new occurrence of $O$. araguaiana demonstrates that a) the paleobiogeographic distribution of this species is wider than previously thought (that it was restricted to the northern part of Paraná Basin, Mato Grosso State); b) the molluscan fauna of the Corumbataí Formation ( $P$. illusa biozone) in the State of São Paulo is more diverse and dominated by megadesmids; and c) the composition of the molluscan fauna of the Corumbataí Formation in Alto Garças, State of Mato Grosso, is essentially the same as that of the P. illusa biozone of the eastern margin of the Paraná Basin.
\end{abstract}

Keywords: Bivalvia; Megadesmidae; Permian; Paraná Basin; Corumbataí Formation; Systematics.

\section{RESUMO}

Nesse estudo, é reportada, pela primeira vez, a ocorrência de Othonella araguaiana Mendes, no Estado de São Paulo, intervalo da biozona de Pinzonella illusa, Formação Corumbataí, Permiano médio. Trata-se de bivalve de ocorrência rara, originalmente descrito para a Formação Estrada Nova (= Formação Corumbataí), do Alto Araguaia e Alto Garças, Estado do Mato Grosso. Novos espécimes de O. araguaiana foram encontrados em arenito bioclástico (tempestito proximal), na parte média da Formação Corumbataí, em Rio Claro, SP. As conchas silicificadas e os moldes internos estão bem conservados, preservando a impressão da musculatura e de outros caracteres internos (e.g., charneira) nunca antes ilustrados. Em sua descrição original, Mendes (1963) chamou a atenção para a semelhança entre O. araguaiana e Terraia aequilateralis, um Veneroida comum na Formação Corumbataí. Contrariamente, Runnegar e Newell (1971), notaram que O. araguaiana 
pertence aos Megadesmidae, se tratando provavelmente de um sinônimo-júnior de Plesiocyprinella carinata (o megadesmídeo mais comum do Grupo Passa Dois). Conforme nossos dados mostram, O. araguaiana pode ser atribuída aos Megadesmidae, sendo, porém, distinta de $P$. carinata. A nova ocorrência de $O$. araguaiana é importante para esclarecer as relações de parentesco entre os Megadesmidae da Bacia do Paraná e por demonstrar que: a) a distribuição paleobiogeográfica da espécie não está restrita à porção setentrional da Bacia do Paraná, no Estado do Mato Grosso; b) a fauna de moluscos bivalves da Formação Corumbataí (biozona de $P$. illusa) no Estado de São Paulo é mais diversa e, de fato, dominada pelos megadesmídeos, e c) a composição da fauna de moluscos da Formação Corumbataí em Alto Garças é essencialmente a mesma da biozona de P. illusa, da borda leste da Bacia do Paraná.

Palavras-chave: Bivalvia; Megadesmidae; Permiano; Bacia do Paraná; Formação Corumbataí; Sistemática.

\section{INTRODUCTION}

The oldest known mollusc-bearing, long-lived endemic bivalve fauna in the world was reported in the Paraná lake/ sea (Passa Dois Group), Late Paleozoic (Wesselingh, 2007). This bivalve fauna, firstly described by Holdhaus (1918), was revised by Runnegar and Newell (1971) and has gained renewed systematic (Simões et al., 1997, Simões, RochaCampos, Anelli, 1998; Mello, 1999), paleoecological (Ghilardi, 1999; Kowalewski et al., 2000; Ghilardi and Simões, 2002), and taphonomic (Torello and Simões, 1994; Simões, Torello, Rocha-Campos, 1996; Simões and Kowalewski, 1998; Simões et al., 2000a; Simões and Torello, 2003) attention during the last decades (Wesselingh, 2007).

During the Permian, the Paraná lake/sea was an aquatic island of diversity and endemicity within a continental interior (Eastern Gondwana) (Runnegar and Newell, 1971; Simões, Rocha-Campos, Anelli, 1998; Wesselingh, 2007). According to Runnegar and Newell (1971), the evolution of the Passa Dois Group molluscan fauna can be considered a distinct chapter in the evolutionary history of Bivalvia Class. Runnegar and Newell (1971) compared the evolution of the Passa Dois Group bivalve fauna with that of Pontian radiation of Caspian and Black seas during the Neogene. Stanley $(1979,1990)$ argued that the isolated Paraná Basin was a site of similar but less dramatic molluscan radiation during the Permian. According to this author, the Paraná Basin illustrates the importance of geographic factors in the control of evolutionary radiations. However, the more realistic scenario of this in situ evolution is obscured by the poor and biased knowledge of the systematics of the Passa Dois Group molluscan fauna. For example, most of the published papers dealing with the systematics of mid- Permian bivalves of the Paraná Basin are from the interval of Pinzonella illusa and Pinzonella neotropica biozones, in the middle and upper portions of the Teresina and Corumbataí formations (Rohn, 1994). Actually, even in the classical monograph of Runnegar and Newell (1971), the bivalves of these two biozones were studied in preference to others. This is because, in such intervals, the bivalves are found in bioclastic sandstones and coquinas, where the shells are silicified and, usually, well preserved. The bivalves of the Irati (Kazubek and Simões, 2003) and Serra Alta formations (Maranhão, 1986) as well as those of the Serrinha and Morro Pelado members of the Rio do Rasto Formation (Rohn, 1994; Rohn and Simões, 1997) are still poorly studied and described. Hence, at the present time, the exact number of species is unknown (due to the poor preservation of some earlier described taxa, mostly from the Serra Alta and Rio do Rasto formations, as well as, the fact that some important systematic studies, such as Maranhão, 1986 and Rohn, 1988, were not be published). The impact of the study on the evolutionary history of this spectacular molluscan fauna is obvious: we do not know well the biodiversity and morphological disparity that resulted from the in situ evolution of the bivalve mollusks within the Paraná lake/sea during the Permian.

Despite the comments above, the continuous search for bivalves in the classical mid-Permian strata, cropping-out in the Corumbataí River valley, in the city of Rio Claro, State of São Paulo, has resulted in the identification of a new bivalve species. In this brief contribution, we presented, by the first time, the occurrence of rare specimens of Othonella araguaiana Mendes, 1963, in the Permian strata of the State of São Paulo. This bivalve mollusk species was originally observed in coeval rocks of the Estrada Nova Formation (= Corumbataí Formation) in the Alto Araguaia and Alto Garças regions, State of Mato Grosso. This new find is important because the studied shells are well preserved, helping us to add new information about the morphology and systematic affinities of this species, a controversial issue since early 60's (see Mendes, 1963; Runnegar and Newell, 1971), as well as, the taxonomic composition of the molluscan fauna of the $P$. illusa biozone.

\section{BACKGROUND}

\section{The enigmatic Othonella araguaiana}

The genus Othonella and the species $O$. araguaiana were proposed by Mendes (1963) for small (length of $\sim 3 \mathrm{~cm}$ ) silicified shells found in coquinas and bioclastic 
sandstones of the Corumbataí Formation, of the State of Mato Grosso. The original material described by Mendes (1963) is housed in the Scientific Collection of Geosciences Institute of the University of São Paulo. This material came from three main sites in the region of the Alto Araguaia River, State of Mato Grosso, where the Permian strata of the Paraná Basin are exposed (see Almeida, 1954).

During the description of $O$. araguaiana, Mendes was particularly impressed by the similarities between the hinge of this species and that of Terraia aequilateralis Mendes, 1952, a veneroid crassatellacean bivalve. Nevertheless, Mendes (1963) did not assign O. araguaiana to any known bivalve order or family. Hence, until 1970, the affinities of $O$. araguaiana remained unclear. However, Runnegar and Newell (1971) and Simões et al. (1997) demonstrated that most of the thick-shelled, infaunal suspensionfeeding bivalves of the Passa Dois Group, bearing a massive blunt tooth in the right valve, could be assigned to Megadesmidae, a compact group of Late Paleozoic marine bivalve mollusks.

Runnegar and Newell (1971, p. 29) considered $O$. araguaiana as a synonym of Plesiocyprinella carinata Holdhaus, 1918, due to the fact that the type specimens of Mendes (1963, Figures 3 and 4) have shell shape and hinge similar to those of $P$. carinata (Runnegar and Newell, 1971, p. 32). In addition, these authors called attention to the poorly preserved nature of Mendes' specimens. However, later in the same paper, Runnegar and Newell (1971, p. 33) considered Othonella as a distinct genus of Megadesmidae. Hence, we could ask if Othonella is indeed a valid genus or a synonym of Plesiocyprinella. The identification of new specimens, as well as, their extensive laboratory preparation made it possible for us to analyze the hinge features and muscle scars and address the issue above.

\section{MATERIAL AND METHODS}

In this study, we have analyzed new specimens of $O$. araguaiana from the Corumbataí Formation (Figures 1 and 2) as well as, the type material of Mendes (1963) from the same lithostratigraphic unit of the State of Mato Grosso. Altogether, six specimens were examined, including five silicified shells and one internal mold. The internal anatomical characters of these specimens, including the muscle scars and hinge, were, described in detail for the first time. The type material (four specimens) is housed in the scientific collection of the Institute of Geosciences, University of São Paulo, under the code DGP-7. The two new studied specimens are reposited in the Scientific Collection of the Department of Zoology, Institute of
Biosciences, São Paulo State University, Botucatu campus, under the code DZP.

The new specimens were found in a sandstone bed in the middle portion of the Corumbataí Formation (middle Permian), P. illusa biozone (sense Rohn, 1994) (Figures 1 and 2). The specimens were collected and prepared using standard paleontological techniques (Feldmann, Chapman, Hannibal, 1989). In the study area, Rio Claro region, the best and most extensively studied exposures of this unit are in the Corumbataí River valley (Figures 1 and 2) (Mendes, 1952; Landim, 1970). For this study, we focused our sampling efforts on the so-called "Ferraz shell bed" (Simões and Kowalewski, 1998), a proximal tempestite bed that is intercalated within a monotonous sequence dominated by violet siltstones with wave and lenticular bedding (Figure 2). This bed is well exposed in a road cut located about $1.5 \mathrm{~km}$ from the abandoned

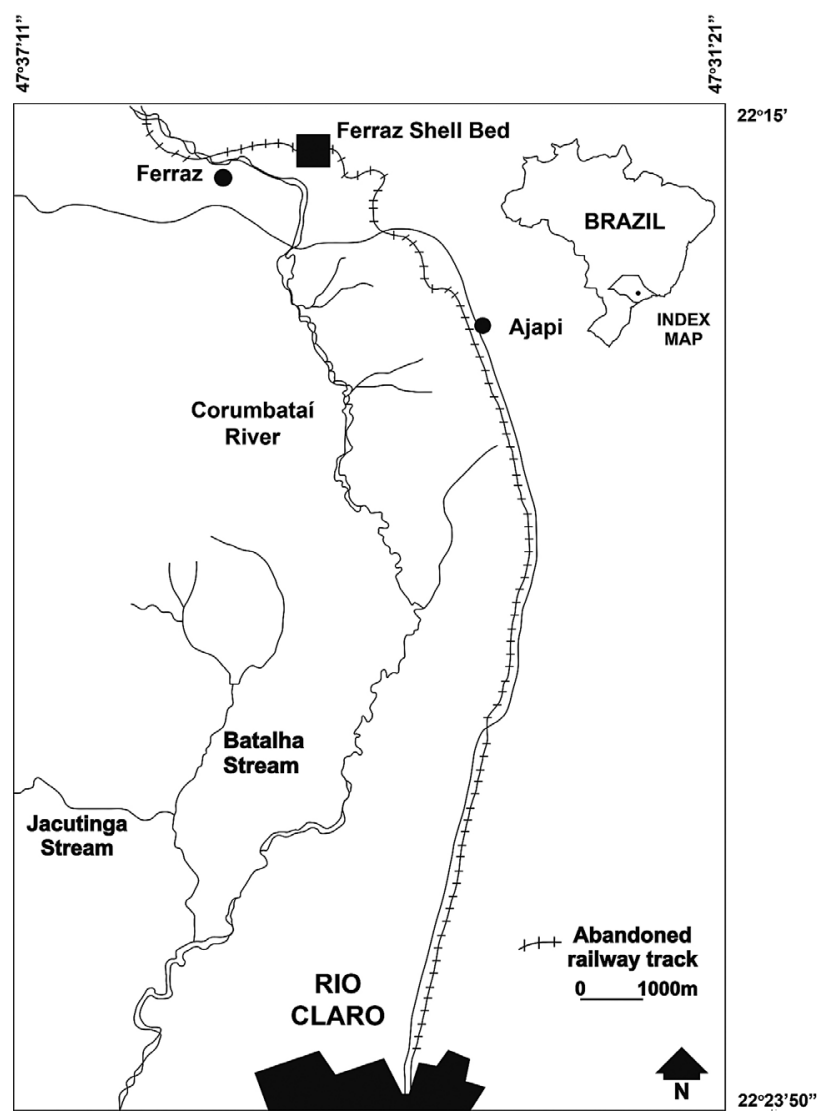

Figure 1. Schematic map of the study area, City of Rio Claro, São Paulo, Brazil, showing the location of the Ferraz shell bed (Simões and Kowalewski, 1998). 


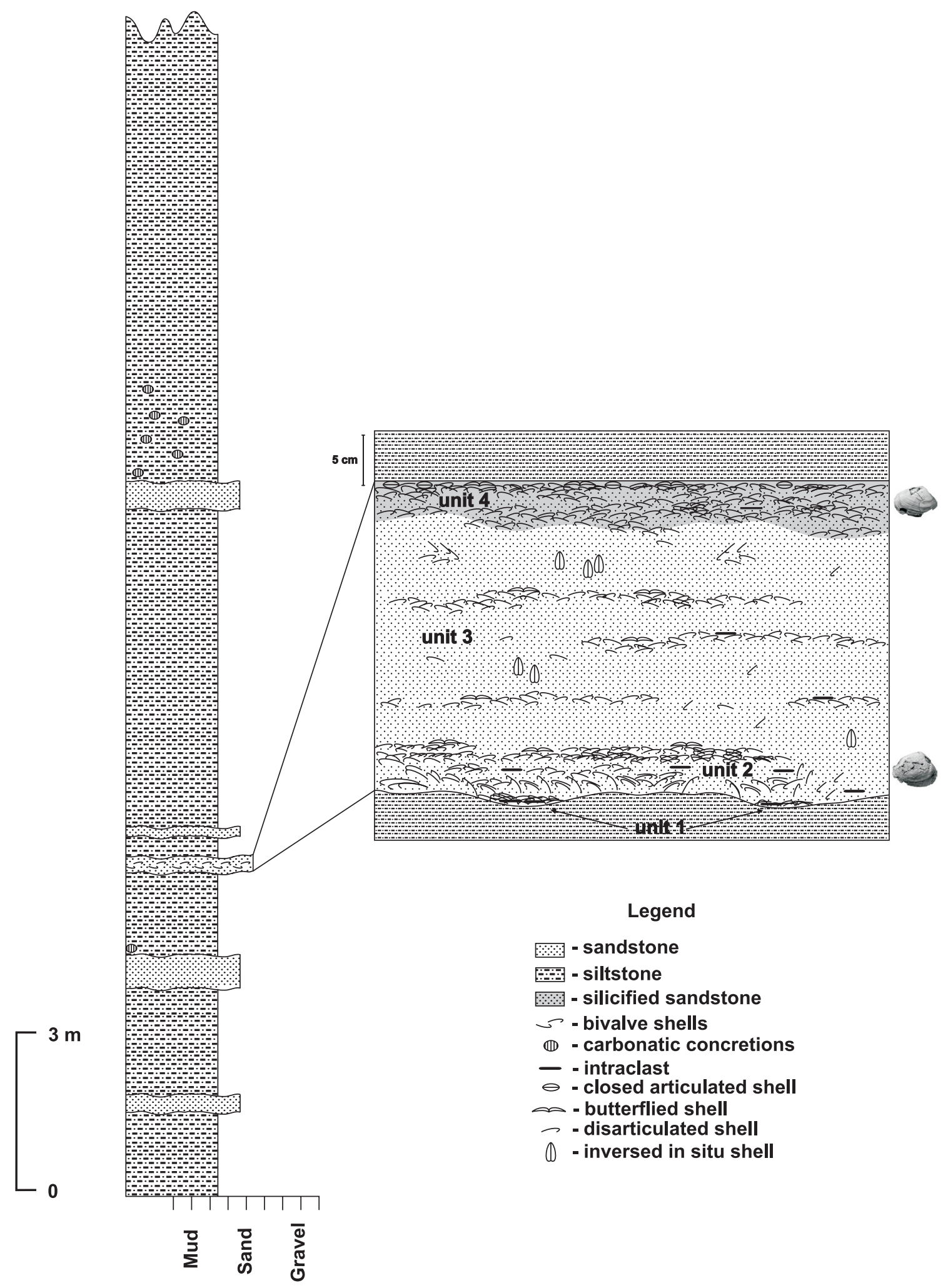

Figure 2. Composite stratigraphic section of the lower and middle part of the Corumbataí Formation, Rio Claro County (see Figure 1), highlighting the Ferraz shell bed (Simões and Kowalewski, 1998). Othonella shells were found in Unit 2 and 4 of the bivalve-rich sandstone. 
Ferraz Railway Station (Figure 1). According to the detailed stratigraphic and taphonomic analysis made by Simões and Kowalewski (1998), the Ferraz shell bed consists of four distinct microstratigraphic units. They include, from bottom to top (Figure 2), a lag concentration (Unit 1), a partly reworked storm deposit (Unit 2), a rapidly deposited sandstone unit with three thin horizons recording episodes of reworking (Unit 3), and a shell-rich horizon generated by reworking/winnowing, which was subsequently buried by storm-induced obrution deposit (Unit 4). The studied specimens of $O$. araguaiana were recorded in the microstratigraphic unit 2 (DZP-17928) and 4 (DZP-2764) (Figure 2).

Finally, the suprageneric systematics is based on Morris, Dickins and Astafieva-Urbaitis (1991), and, at the family level, on Runnegar and Newell (1971), Runnegar (1974) and Simões et al. (1997).

\section{RESULTS}

\section{Systematic Paleontology}

Family MEGADESMIDAE Vokes, 1967

Subfamily PLESIOCYPRINELLINAE Simões et al., 1997 Othonella Mendes, 1963

Diagnosis. Shell elongated, sub-triangular, nongaped, with faintly marked umbonal carina. Hinge of right valve with an elongated, non-bifid, megadesmid tooth. Pallial line non-sinuate, striated and anteriorly dotted, not crossing adductor muscle scars; umbonal elevator and accessory muscle scars ( $\mathrm{a}, \mathrm{b}$, ava) absent; mantle muscle (pits) present. Anterior adductor, pedal and protractor muscle scars not fused.

Type-species. Othonella araguaiana Mendes, 1963, by monotypy and original designation.

\section{Othonella araguaiana Mendes, 1963}

Figure 3
Type-material. The lectotype (here designated) is DGP 7-982 (Mendes, 1963, Figures 3a and 3b) from $P$. illusa biozone, Estrada Nova Formation (= Corumbataí Formation), was found in a coquina from Alto Garças, Mato Grosso, near the old powerhouse unit. The paratypes (here designated) are DZP-2764 and DZP-17928 from the $P$. illusa biozone, Corumbataí Formation, found in a sandstone bed (Ferraz shell bed) from Rio Claro, São Paulo.

Diagnosis. Shell small ( $\sim 3 \mathrm{~cm}$ in length, see Table 1), elongated, sub-triangular, with a well defined non-bifid, blunt tooth in the right valve, and a corresponding socket in the left valve. Anterior adductor muscle scar subquadrate; posterior adductor muscle scar elongated, placed behind umbonal carina. Anterior adductor, pedal and protractor muscle scars not fused. Pallial line relatively wide, without pallial sinus, striated and anteriorly dotted, not crossing adductor muscle scars. Accessory muscle scars absent.

Description. Shell sub-triangular, thick, equivalved, inequilateral, moderately elongated, inflated (Figures 3A, 3B, 3D, 3I). Umbonal region low, with slightly prosogyrous beaks (Figures 3G and 3I), slightly elevated above hinge area; posterior umbonal carina rounded, faintly marked (Figure 3H). Lunule and escutcheon absent. Shell surface ornamented with well-marked growth lines of varying width, irregularly spaced (Figure $3 \mathrm{H}, \mathrm{J}$ ). Ligament opisthodetic, parivincular, external, attached by short nymphs (Figure 3I). Anterior dorsal margin straight, anterior extremity rounded; ventral margin convex, posteriorextremity truncated with poorly definedrespiratory margin; posterior dorsal margin straight. Hinge of right valve with anterior triangular socket, followed posteriorly by triangular blunt tooth (Figures 3A, 3D, 3I, 3K). Hinge of left valve with anterior triangular blunt tooth followed posteriorly by deep triangular socket (Figure 3G). Lateral teeth absent. Adductor muscle scars anisomyarian (Figure 3C). Anterior adductor scar dorsoventrally elongated, close to the anterior margin; anterior pedal protractor and retractor scars small, positioned above adductor, not fused (Figure 3C). Posterior adductor scar larger than anterior,

Table 1. Measurements of silicified shells of Othonella araguaiana.

\begin{tabular}{cccccc}
\hline Specimen & Valve & Preservation & Length $\mathbf{~ m ~}$ & Height $\mathbf{m}$ m & Elongation \\
\hline DGP-7/980 & Right & fragmented & - & - & - \\
DGP-7/981 & Left & complete & 29.0 & 24.5 & 1.20 \\
DGP-7/982 & Right & complete & 30.6 & 24.0 & 1.25 \\
DGP-7/983 & Left & complete & 30.0 & 24.0 & 1.25 \\
DZP-2764 & Right & complete & 36.4 & 26.4 & 1.40 \\
\hline
\end{tabular}



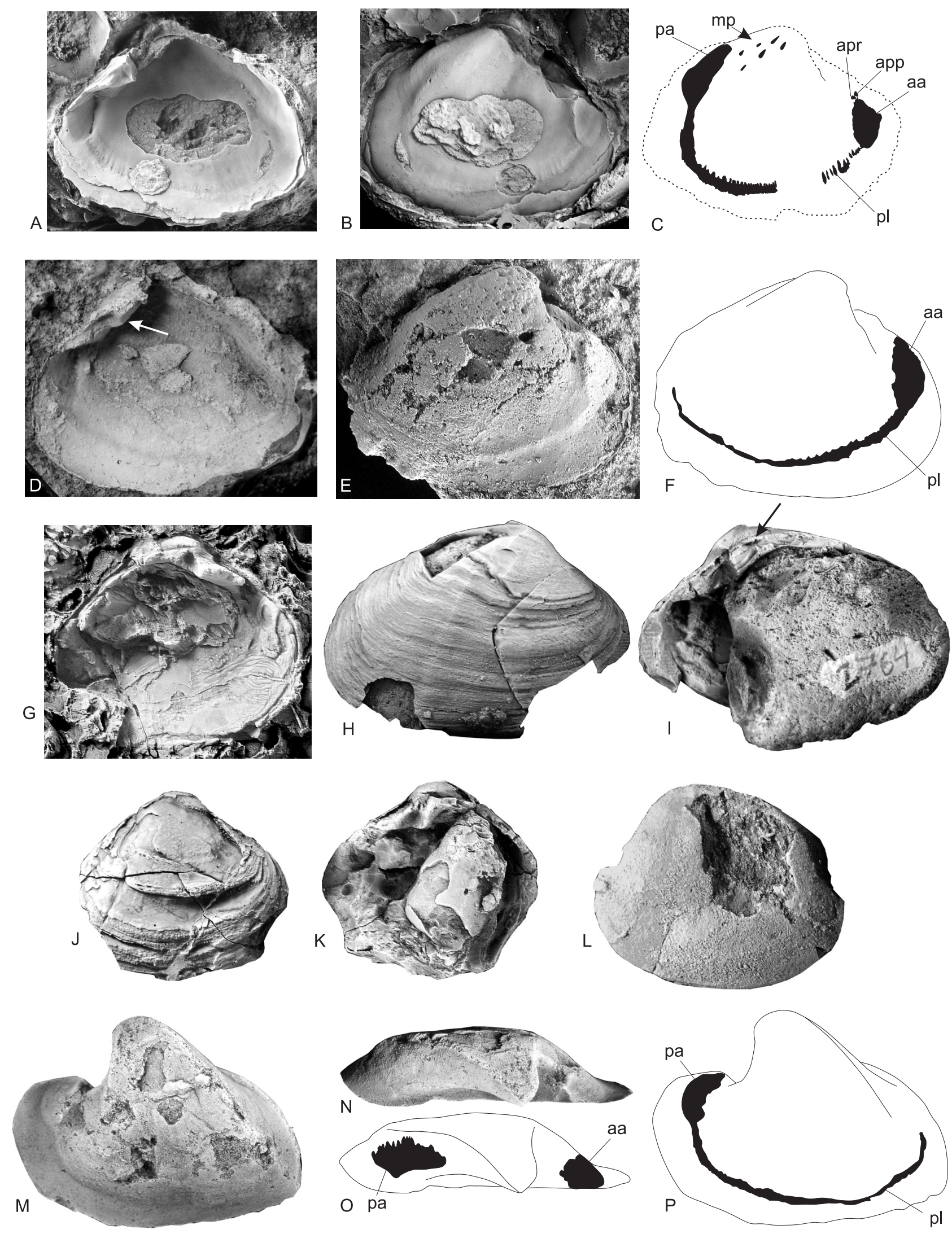
elongated dorsoventrally, placed behind umbonal carina; posterior pedal retractor and protractor scars not observed (Figure 3C). Accessory muscle scars (a, b, and ava, see Runnegar, 1974) absent (Figure 3C). Pallial line wide, well marked, striated, anteriorly dotted, without sinus (Figure 3C). Muscular pits scars present on the umbonal area (Figure 3C).

Stratigraphic Range. Pinzonella illusa biozone (Mendes, 1952; Rohn, 1994) in both states, São Paulo and Mato Grosso.

Discussion. Based on the shell shape, Runnegar and Newell $(1971$, p. 29,31$)$ suggested that $O$. araguaiana could be a junior subjective synonym of $P$. carinata. As shown in figure 3 , the shell profiles of both species are distinct. Shells of $P$. carinata are more triangular, with high, enrolled umbones, and a well marked umbonal carina (Figures $3 \mathrm{~m}$ to $3 \mathrm{p}$ ). In addition, in the right valve of $P$. carinata, there is a massive cardinal bifid tooth, with the concave ventral surface fitting a prominent ridge in the center of the socket of the left valve (Runnegar and Newell, 1971, p. 30, Figure 8b; p. 31, Figure 9a). The megadesmid tooth in the right valve of $O$. araguaiana is not as massive as in P. carinata, and nor is bifid. Despite the dissimilarities in the hinge, the shape and size of the anterior muscle scars in $P$. carinata (Figures $3 \mathrm{~m}$ to $3 \mathrm{p}$ ) and $O$. araguaiana are very similar. On the other hand, the general pattern of the muscle scar arrangement in O. araguaiana, including the striated pallial line and muscular pits on the umbonal cavity, resembles that of the megadesmid Runnegariella fragilis (Simões and Anelli, 1995, p. 168, Figure 6). However, the general shell shape of both species is completely distinct, and, in addition to that, $R$. fragilis has its anterior margin unusually expanded. In summary, despite the affinities with other Permian megadesmids of the Passa Dois Group, $O$. araguaiana is a distinct member of the endemic fauna of the P. illusa biozone.

\section{DISCUSSION}

\section{Biostratigraphic and evolutionary implications}

According to our results, shells of $O$. araguaiana are present in the rocks of the interval of the P. illusa biozone (Figure 4) of the eastern border of Paraná Basin. This indicates that this species, which was reported to be restricted to the northern border of the basin, Mato Grosso region, has a wider paleobiogeographic distribution than previously thought. In the State of Mato Grosso, the $P$. illusa biozone includes the following species: Terraia aequilateralis, Plesiocyprinella carinata, Holdhusiella elongate Holdhaus, 1918, Ferrazia cardinalis Reed, 1932, Cowperesia sp., plus O. araguaiana. In the type area of the P. illusa biozone, Corumbataí River valley, State of São Paulo, the sedimentary strata have yielded exactly the same taxa mentioned above, plus Roxoa intricans Mendes, 1952, Coxesia mezzalirai Mendes, 1952, Favalia arcuata Mendes, 1962, and other undescribed shells. In other words, the Permian bivalve association of Alto Garças, Mato Grosso, is the same of that of the Corumbataí Formation from the State of São Paulo, where the main horizons are found 50 meters below the Pinzonella neotropica interval (Mendes, 1952, 1963). The fact that, in the type area of the Corumbatai Formation, the $P$. illusa association is more diverse is, in part, a sampling bias. The "Ferraz shell bed" and other coeval bioclastic sandstones of the Corumbataí Formation are among the most sampled Permian strata in the state (or even in the basin). Based on our experience with the Permian bivalves of the Paraná Basin, the intensity and duration of sampling program are important (Simões et al., 2000b), since both, quality and quantity, are expanded with the increase in sampling effort (see also Newell and Boyd, 1995; Newell, 1999).

Figure 3. A-L: Othonella araguaiana Mendes, 1963, Corumbataí Formation, Middle Permian. A. Internal view of a silicified right valve, DGP 7-982, x1.5. B. Latex cast of the internal surface of right valve, same specimen, x1.5. C. Muscle scars based on the latex cast of the same specimen, x1.5. D. Latex cast of an internal mold of right valve, arrow indicates the megadesmid blunt tooth, DZP-17328, x1.5. E. Internal mold of right valve, DZP-17328, x1.5. F. Muscle scars based on the same specimen, x1.5. G. Internal view of a silicified left valve, DGP 7-983, x1.5. H. External view of a silicified right valve, DZP-2764, x1.5. I. Internal view of a silicified right valve, showing hinge features and nymph (arrow), same specimen, x1.5. J. External view of a silicified right valve, DGP 7-980, x1.5. K. Internal view of a silicified right valve, showing hinge features, same specimen, x1.5. L. External view of a silicified left valve, DGP 7-981, x1.5. M-P: Plesiocyprinella carinata (Holdhaus) 1918, Corumbataí Formation, Middle Permian. M. Left valve view of an internal mold, DZP-647, x1,3. N. Dorsal view of an internal mold, same specimen, x1.3. O. Muscle scars based on the same specimen, dorsal view, x1.3. P. Muscle scars based on the same specimen, left valve view, x1.3. Legend (muscles scars): $\mathbf{a a}=$ anterior adductor, $\mathbf{a p p}=$ anterior pedal protractor, apr $=$ anterior pedal retractor, $\mathbf{m p}=$ muscles pits, $\mathbf{p a}=$ posterior adductor, $\mathbf{p l}=$ pallial line. 


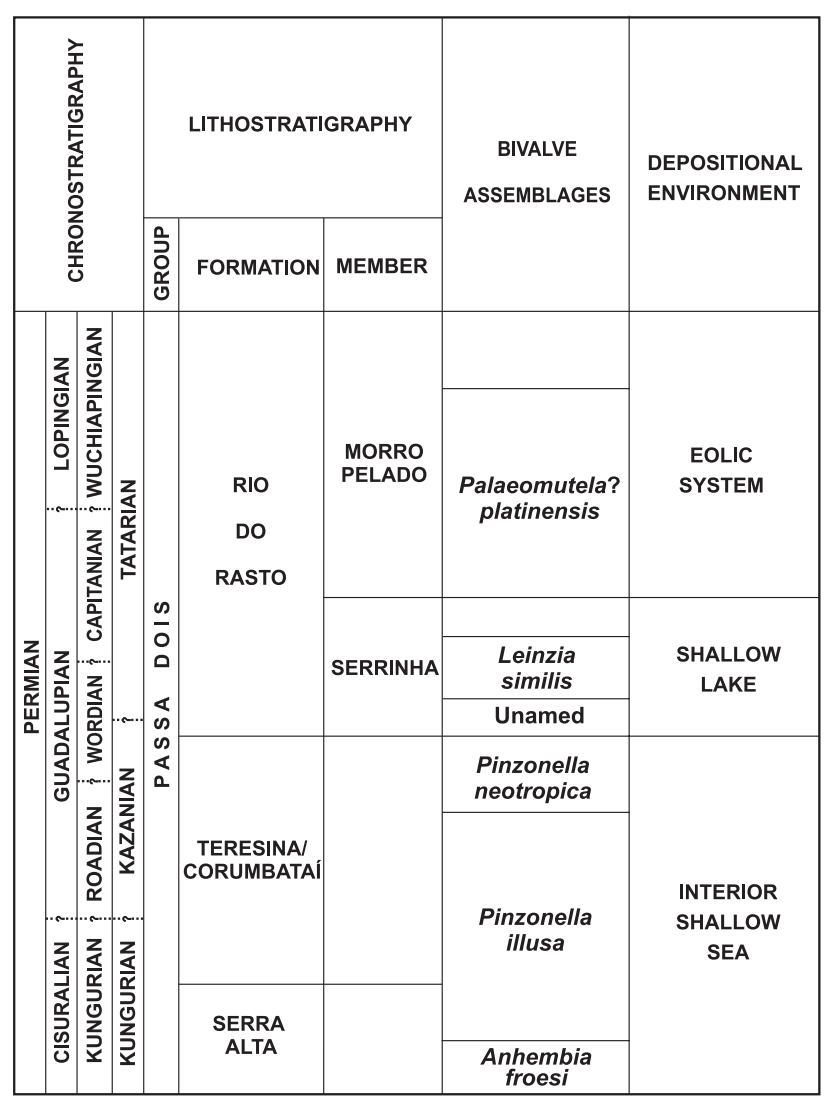

Figure 4. Schematic chart of the Passa Dois Group, Permian, showing the bivalve biozones of the eastern margin of the Paraná Basin (based on Rohn, 1994, 2007).

As described above, the spatial homogeneity of the fauna of the interval of $P$. illusa biozone cannot be easily explained within the paleogeographic context of Paraná lake/sea, during the mid Permian. There is a consensus that during the deposition of the Corumbataí Formation, the basin was mostly isolated from the open ocean waters, when siliciclastic, subtidal and intertidal settings prevailed. After the maximum flooding stage (Palermo and Irati formations) and still-stand (black shales of the Irati Formation) the sea level began to fall slowly, and the Paraná Basin became isolated (Beurlen, 1957; Runnegar and Newell, 1971; Simões et al., 1997; Simões, RochaCampos, Anelli, 1998). In this moment, the lake/sea was formed. During the deposition of the extensive organic-rich clays of the Irati Formation, widespread anoxic conditions prevailed in the basin. This interval represents an ecological crisis for the benthos (Runnegar and Newell, 1971; Simões, Rocha-Campos, Anelli, 1998; Wesselingh, 2007). The regressive phase that set in during the deposition of the Teresina and Corumbataí formations was accompanied by the "explosive" and abrupt appearance of an endemic, diverse, bivalve-dominated fauna, mostly represented by burrowing species of Heterodonta (Astartidae) and Anomalodestama (Megadesmidae). The main associations of this interval are represented, from base to top, by the bivalve species of the Anhembia froesi Mendes, 1949, $P$. illusa and P. neotropica biozones (sense Rohn, 1994) (Figure 4). Based on the stratigraphic record of the Passa Dois Group, Rio Claro region, State of São Paulo, the oldest known occurrences of the endemic bivalves of the Corumbataí Formation are found nearly 5.02 meters above the base of the Irati Formation (Simões et al., 2000b).

Our results indicate that during the deposition of part of the interval of the P. illusa biozone, the bivalve species were not geographically restricted to certain areas within the basin (see also Rohn et al., 1995), as previously thought. How and why the bivalve species became widely distributed in the whole lake/sea in certain intervals (P. illusa, $P$. neotropica biozones) must be carefully investigated. The basic evolutionary model may involve $3^{\text {rd }}$ order relative sea level fluctuations, which caused significant onlap variations, due to the very low depositional gradients of the basin (see Rohn et al., 1995; Simões, Rocha-Campos, Anelli, 1998). In this context, the relative base level falls are related to climatic-controlled variations in the water supply to the basin interior, causing "regressions", during arid or semi-arid and no tectonic activity phases (see Rohn, 1994). This may have been the time of faunal isolation and in situ evolution, which was followed by water level rises ("transgressions"), during the humid phases, in part, associated with tectonic events, when the fauna reached maximum distribution within the basin. However, the records of mid-Permian cosmopolitan freshwater bivalve groups in the interval of $P$. illusa and $P$. neotropica biozones are missing. On the other hand, the recent finds of macro- and microfossils with "true" marine affinities, both in the eastern (brachiopods, Simões and Anelli, 2009), and northern (ostracods, Almeida, 2005; Tomassi and Do Carmo, 2008, 2009; Tomassi, 2009) margins of the basin, may indicate that within the regressive sequence, the drop of sea level could be interrupted by short-lived sea level rises or pulses, showing that the evolution of the bivalvedominated faunas of the Passa Dois Group is much more complex than stressed in the early evolutionary models (Beurlen, 1957; Runnegar and Newell, 1971; Simões, Rocha-Campos, Anelli, 1998).

\section{Future research opportunities}

Despite the advances in our understandings about the evolution of bivalve faunas in the Paraná lake/sea (Runnegar and Newell, 1971; Simões et al., 1997; Simões, 
Rocha-Campos, Anelli, 1998), some key issues (e.g., the ecological context of speciation) are still poorly explored and/or understood. As for other long-lived lake/sea bivalve faunas, much remains to be learned about their evolution, and an absolute prerequisite for this is a combined approach, including rigorous taxonomic, stratigraphic, taphonomic and paleoautoecological treatments of the faunas (see Wesselingh, 2007). Nearly 90 years after the pioneer study of Holdhaus (1918), many bivalve-dominated faunas of the Passa Dois Group in the Brazilian portion of Paraná Basin are still poorly documented or undescribed. Particularly unique opportunities for this type of studies are offered by the faunas of the Irati and Serra Alta formations (in the base of the Passa Dois Group), and the Serrinha Member of the Rio do Rasto Formation, at the top of the Passa Dois Group.

\section{CONCLUSIONS}

1. Othonella araguaiana Mendes is a rare bivalve species of the endemic molluscan fauna of the Passa Dois Group ( $P$. illusa biozone). Here we report, for the first time, the presence of this species in Permian rocks of the Corumbataí Formation, cropping-out in the State of São Paulo. The studied shells are better preserved than those originally described by Mendes (1963), preserving various internal shell characters (e.g., muscle scars, hinge), which allowed a clearer association between them and the other Permian bivalves of the Paraná Basin (more refined designation of its affinities with other Permian bivalves of the Paraná Basin).

2. As previously noted by Runnegar and Newell (1971), $O$. araguaiana belongs to Megadesmidae. However, these authors suggested that this species was conspecific with Plesiocyprinella carinata. As discussed above, the study of new specimens found in "Ferraz shell bed", Rio Claro region, State of São Paulo, and a more careful reexamination of type specimens of Mendes (1963) showed that Othonella is a valid genus of Megadesmidae, with shell shape and hinge clearly distinct from those of Plesiocyprinella.

3. The considerations discussed above have important systematic, evolutionary and biostratigraphicimplications, since the new occurrence of $O$. araguaiana in midPermian rocks of eastern margin of the Paraná Basin, demonstrates that: a) the paleobiogeographic distribution of this species is wider than previously reported and not confined to the northern part of the basin; and b) the composition of the molluscan fauna of the Corumbataí Formation of the State of Mato Grosso (northern margin) is the same of the P. illusa biozone found in the eastern margin of the Paraná Basin.

\section{ACKNOWLEDGEMENTS}

We would like to thank the undergraduate students Rafaela Lopes Falaschi and Marcos Bizarro Junior for the initial laboratory preparation of the studied specimens. The final version of this paper was improved thanks to the careful review and comments of Luiz Ricardo L. Simone and Carla Bender Kotzian. This study is a contribution to the following projects: FAPESP (96/9708-9), and CNPq (500694/92-3, 151853/2008-8).

\section{REFERENCES}

ALMEIDA, C. M. Taxonomia e paleocologia de ostracodes do Permiano da bacia do Paraná, Estado de Goiás, Brasil: considerações paleoambientais e cronoestratigráficas. 2005. 42 f. Dissertação (Mestrado) - Instituto de Geociências, Universidade de Brasília, Brasília, Distrito Federal, 2005.

ALMEIDA, F. F. M. de. Geologia do centro-leste matogrossense. Boletim do Departamento Nacional de Produção Mineral, v. 150, p. 1-97, 1954.

BEURLEN, K. Faunas salobras fósseis e o tipo ecológico-paleogeográfico das faunas Gondwânicas no Brasil. Anais da Academia Brasileira de Ciências, v. 29, p. 229-241, 1957.

FELDMANN, R. M.; CHAPMAN, R. E.; HANNIBAL, J. T. Paleotechniques. Knoxville: The Paleontological Society Special Publication, 1989. 358 p. (Special publication; n. 4 )

GHILARDI, R. P. Paleoautoecologia dos bivalves do Grupo Passa Dois (Neopermiano), no Estado de São Paulo: bivalves fósseis como indicadores da dinâmica sedimentar. 1999. 160 f. Dissertação (Mestrado) - Instituto de Geociências, Universidade de São Paulo, São Paulo, 1999.

GHILARDI, R. P.; SIMÕES, M. G. Foram os bivalves do Grupo Passa Dois (Exclusive Formação Rio do Rasto), Neopermiano, invertebrados tipicamente dulcícolas? Pesquisas em Geociências, v. 29, p. 91-99, 2002.

HOLDHAUS, K. Sobre alguns lamelibranchios fósseis do sul do Brasil. Serviço Geológico e Mineralógico do Brasil, Monografias, v. 2, p. 1-24, 1918.

KAZUBEK, M. F.; SIMÕES, M. G. Permian bivalves of the Irati Formation (Passa Dois Group, Paraná Basin) and their paleoecological significance. In: CONGRESSO 
BRASILEIRO DE PALEONTOLOGIA, 18., 2003, Brasília. Boletim de Resumos... Brasília: SBP, 2003, p. 161.

KOWALEWSKI, M.; SIMOES, M. G.; TORELLO, F. F.; MELLO, L. H. C ; GHILARDI, R. P. Drill holes in shells of Permian benthic invertebrates. Journal of Paleontology, v. 74, p. 532-543, 2000.

LANDIM, P. M. B. O Grupo Passa Dois (P) na Bacia do Rio Corumbataí. Boletim da Divisão de Geologia e Mineralogia, Departamento Nacional de Produção Mineral, v. 252 , p. $1-103,1970$.

MARANHÃO, M. S. A. S. Contribuição ao conhecimento da malacofauna das camadas basais da Formação Corumbatai (Permiano) Estado de São Paulo. 1986. 89 f. Dissertação (Mestrado) - Instituto de Geociências, Universidade de São Paulo, São Paulo, 1986.

MELLO, L. H. C. Análise claíistica dos bivalves do Grupo Passa Dois (Neopermiano), Bacia do Paraná, Brasil: implicações taxonômicas, evolutivas e paleobiogeográficas. 1999. 160 f. Dissertação (Mestrado) - Instituto de Geociências, Universidade de São Paulo, São Paulo, 1999.

MENDES, J. C. A Formação Corumbataí na região do Rio Corumbataí (estratigrafia e descrição dos lamelibrânquios). Boletim da Faculdade de Filosofia Ciências e Letras. Série Geologia, v. 145, v. 8, p. 1-119, 1952.

MENDES, J. C. Lamelibrânquios permianos do Estado do Mato Grosso (Formação Estrada Nova). Boletim da Sociedade Brasileira de Geologia, v. 12, p. 57-64, 1963.

MORRIS N. J.; DICKINS, J. M.; ASTAFIEVAURBAITIS, K. Upper Paleozoic Anomalodesmatan Bivalvia. Bulletin of the British Museum of Natural History (Geology), v. 47, p. 51-100, 1991.

NEWELL, N. D. A new limoid bivalve from the Texas Middle Permian. American Museum Novitates, n. 3264, p. 1-6, 1999.

NEWELL, N. D.; BOYD, D. W. Pectinoid bivalves of the Permian-Triassic crisis. Bulletin of the American Museum of Natural History, v. 227, p. 1-95, 1995.

ROHN, R. Bioestratigrafia e paleoambientes da Formação Rio do Rasto na borda leste da Bacia do Paraná (Permiano Superior, Estado do Paraná). 1988. 2 v. Dissertação (Mestrado) - Instituto de Geociências, Universidade de São Paulo, São Paulo, 1988.
ROHN, R. Evolução ambiental da Bacia do Paraná durante o Neopermiano no leste de Santa Catarina e do Paraná. 1994. 2 v. Tese (Doutorado) - Instituto de Geociências, Universidade de São Paulo, São Paulo, 1994.

ROHN, R. The Passa Dois Group (Paraná Basin, Permian): investigations in progress. In: WORKSHOP - PROBLEMS IN THE WESTERN GONDWANA GEOLOGY, SOUTH AMERICA - AFRICA CORRELATIONS: DU TOIT REVISITED, 1., 2007, Gramado. Extended Abstracts... Porto Alegre: UFRG, 2007. p. 151-157.

ROHN, R.; SIMÕES, M. G. Pelecypods of the basal Serrinha Member (Rio do Rasto Formation, Passa Dois Group, Upper Permian) at the Reserva-Cândido de Abreu region of the Paraná State. In: CONGRESSO BRASILEIRO DE PALEONTOlOGIA, 15., 1997, São Pedro. Boletim de Resumos... São Pedro: SBG, 1997. p. 72.

ROHN, R.; PERINOTTO, J. A. J.; FULFARO, V. J.; SAAD, A. R.; SIMÕES, M. G. On the significance of the Pinzonella neotropica assemblage (Upper Permian) for the Paraná Basin-Brazil and Paraguay. In: SIMPÓSIO SUL-BRASILEIRO DE GEOLOGIA, 11., 1995, Porto Alegre. Boletim de Resumos Expandidos... Porto Alegre: SBG, 1995. p. 260-261.

RUNNEGAR, B. Evolutionary history of the bivalve Subclass Anomalodesmata. Journal of Paleontology, v. 48, p. 904-939, 1974.

RUNNEGAR, B.; NEWELL, N. D. Caspian-like relict molluscan fauna in South American Permian. Bulletin of the American Museum of Natural History, v. 146, p. 1-66, 1971.

SIMÕES, M. G.; ANELLI, L. E. Runnegariella, um novo gênero de Megadesmidae (Pelecypoda) da Formação Corumbataí (Neopermiano), Bacia do Paraná, Brasil. Revista Geociências, v. 14, p. 161-173, 1995.

SIMÕES, M. G.; ANELLI, L. E. Unusual small shelly fauna (bivalve mollusks and brachiopods) from the Permian micritic limestones of the Teresina Formation, Paraná basin, Brazil. In: CONGRESSO BRASILEIRO DE PALEONTOLOGIA, 21., 2009, Belém. Boletim de Resumos... Belém: SBP, 2009. 1 CD-ROM.

SIMÕES, M. G.; KOWALEWSKI, M. Shell beds as paleoecological puzzles: a case study from the Upper Permian of the Paraná Basin, Brazil. Fácies, v. 38, p. 175-196, 1998. 
SIMÕES, M. G.;TORELLO, F. F. Modelo de tafofácies para os moluscos bivalves do Grupo Passa Dois (Formações Serra Alta, Teresina e Corumbataí), Permiano Superior, Bacia do Paraná, Brasil. Revista Brasileira de Geociências, v. 33, p. 1-10, 2003.

SIMÕES, M. G.; TORELLO, F. F.; ROCHA-CAMPOS, A. C. Gênese e classificação da Coquina de Camaquã, Formação de Corumbataí (Neopermiano), na Região de Rio Claro, SP. Anais da Academia Brasileira de Ciências, v. 68, p. 545-557, 1996.

SIMÕES, M. G.; MARQUES, A. C.; MELLO, L. H. C.; ANELLI, L. E. Philogenetic analysis of the genera of the extinct family Megadesmidae (Pelecypoda, Anomalodesmata), with remarks on its paleoecology and taxonomy. Journal of Comparative Biology, v. 2, p. 75-90, 1997.

SIMÕES, M. G.; ROCHA-CAMPOS, A. C.; ANELLI, L. E. Paleoecology and evolution of Permian pelecypod assemblages (Paraná Basin) from Brazil. In: JOHNSTON, P. A.; HAGGART, J. W. Bivalves - An Eon of evolution: paleobiological studies honoring Norman D. Newell. Calgary: University of Calgary Press, 1998, p. 443-452.

SIMÕES, M. G.; KOWALEWSKI, M.; TORELLO, F. F.; GHILARDI, R. P.; MELLO, L. H. C. Early onset of Modern-Style shell beds in the Permian sequences of the Parana basin: implications for the Phanerozoic trend in bioclastic accumulations. Revista Brasileira de Geociências, v. 30, p. 499-503, 2000a.

SIMÕES, M. G.; TORELLO, F. F.; MELLO, L. H. C.; GHILARDI, R. P. O conteúdo fossilífero de novos afloramentos do Grupo Passa Dois (Neopermiano), nas porções centro sul e nordeste do Estado de São Paulo: implicações bioestratigráficas e paleoecológicas. Acta Geologica Leopoldensia, v. 23, p. 61-90, 2000b.

STANLEY, S. M. Macroevolution, Pattern and Process. San Francisco: W. H. Freeman and Company. 1979, 332 p.

STANLEY, S. M. Adaptive radiation and macroevolution. Systematics Association Special Volume, v. 42, p. 1-16, 1990.

TOMASSI, H. Z. Taxonomia, tafonomia e paleoecologia de ostracodes (Crustacea) da Formação Corumbataí, Permiano da bacia do Paraná: Estado de Goiás, Brasil. 2009. 91 p. Dissertação (Mestrado) - Instituto de Geociências, Universidade de Brasília, Brasília, Distrito Federal.
TOMASSI, H. Z.; DO CARMO, D. A. A ocorrência do gênero Silenites Coryel e Booth, 1933 na Formação Corumbataí (Grupo Passa Dois, Permiano), Bacia do Paraná. In: CONGRESSO BRASILEIRO DE GEOLOGIA, 44., 2008, Curitiba. Anais...São Paulo: SBG, 2008, p. 777.

TOMASSI, H. Z.; DO CARMO, D. A. Taxonomy of Permian Ostracoda from Irati and Corumbataí formations in the northern Paraná basin. In: INTERNATIONAL SYMPOSIUM ON OSTRACODA, 16., 2009, Brasília. Boletim de Resumos... Brasília: ISSO, 2009.

TORELLO, F. F.; SIMÕES, M. G. Características tafonômicas da assembléia de Pinzonella illusa Reed, Formação Corumbataí (Neopermiano), Bacia do Paraná, Brasil. Acta Geologica Leopoldensia, v. 39, p. 159-173, 1994.

WESSELINGH, F. P. Long-lived lake molluscs as island faunas: a bivalve perspective. In: RENEMA, W. Biogeography, time and place: distributions, barriers and islands. Dordrecht: Springer, 2007. p. 275-314. 